\title{
POJAV ZNIŽANE MEJE SNEŽENJA NA OBMOČJU DOLINE PLANICE IN PEČI (TROMEJE)
}

\author{
Danijela Strle*, dipl. geografinja, dr. Matej Ogrin** \\ * Osredek I2a, SI-I 380 Cerknica \\ ** Oddelek za geografijo Filozofske fakultete Univerze v Ljubljani, \\ Aškerčeva 2, SI-I000 Ljubljana \\ e-pošta: danijela.strle@gmail.com, matej.ogrin@ff.uni-lj.si \\ Izvirni znanstveni članek \\ COBISS 1.01 \\ DOI: $10.4312 /$ dela.45.6.101-118
}

\section{Izvleček}

V prispevku analiziramo padavinski dogodek v noči s 25. na 26. marec 2016 ob prehodu hladne fronte. Analiza temperaturnih razmer na proučevanem območju (dolina Planice in Peč) pokaže, da v času padavin v višinah pod $2500 \mathrm{~m}$ ni bilo hladne advekcije. Podatki kažejo celo rahel porast temperature. Vendar pa so v času najmočnejših padavin temperature na naših temperaturnih postajah padle blizu ledišča in za kratek čas je bil nad Planico oblikovan izotermni profil, tako da je za nekaj ur snežna meja dosegla dolinsko dno. Podatki tudi kažejo, da je v času najmočnejših padavin in ohlajevanja nastopilo skoraj brezvetrje, kar kaže na to, da sta dolinska atmosfera in atmosfera nad njo v smislu advekcije in posledično temperaturnih sprememb v času znižane meje sneženja povsem ločeni.

Ključne besede: znižana meja sneženja, dolina Planice, Peč (Tromeja), Slovenija, topoklima, sneg, padavine

\section{LOWERED SNOW LINE PHENOMENON INTHE AREA OF PLANICA VALLEY AND MT. PEČ (TROMEJA)}

\section{Abstract}

In the paper we analyze the precipitation event on the night from March $25^{\text {th }} 2015$ to March $26^{\text {th }} 2015$ during the passage of the cold front. Analysis of temperature conditions in meteorological stations around the studied area (Planica Valley and Mt. Peč) shows that during the precipitation event there was no cold advection under $2500 \mathrm{~m}$. In fact, data showed even small temperature rise. However, during the period of the strongest precipitation, temperatures on our monitoring stations fell close to freezing point and for short period isotherm profile was formed in the Planica Valley. Consequently, snow line reached valley bottom for a few hours. Data also show that during strongest precipitation and cooling, wind speed at the valley bottom decreased to almost calm, which indicates decoupling of air in the lower part of the valley from the air above.

Key words: lowered snow line, Planica Valley, Peč (Tromeja)/Dreiländereck/Monte Forno, Slovenia, topoclimate, snow, precipitation 


\section{UVOD}

Topoklimatske poteze gorskih pokrajin so raznolike in njihova pestrost pogosto preseneča tudi izkušene poznavalce. To se kaže tudi pri padavinah, tako gradientih količine padavin na kratke razdalje kot tudi razlikah v vrsti padavin, kadar gre za tako imenovane mejne situacije, ko majhne razlike atmosferskih pogojev (zlasti temperature) lahko pomenijo veliko razliko $\mathrm{v}$ vremenu in njegovih posledicah. V hladni polovici leta je ob padavinskih dogodkih pogosto vprašanje, kako nizko bo snežilo oziroma na kateri višini bo meja sneženja. Ne glede na to, da so vremenske napovedi vse bolj točne in tudi vse bolj podrobne, obiskovalec gorskih pokrajin v času padavin pogosto ugotovi, da meja sneženja zelo variira od doline do doline, hkrati pa se lokalno lahko nahaja precej nižje, kot jo je postavila vremenska napoved. Primeri, ko je meja sneženja zelo neenakomerno razporejena na ožjem območju, so znani in razlogi za to so lahko različni. Če gre za proces tople ali hladne advekcije kot posledice prehoda vremenske fronte, take razlike niso presenetljive in so tudi lažje napovedljive. Zgodi pa se, da v precej enakomernih splošnih temperaturnih pogojih, torej isti zračni masi, meja sneženja zelo niha med območji, ki so si blizu. Ta pojav v strokovnem žargonu imenujemo znižana meja sneženja (ZMS), ki pomeni, da je lokalno meja sneženja precej nižja od pričakovane, ne pojasni pa razloga za ta pojav. Čeprav je raziskovalcem podnebja in gorskih pokrajin ta pojav splošno poznan, se mu v Sloveniji v zadnjih letih podrobneje ni posvetil še nihče. S topoklimo gorskih območij se v zadnjih letih ukvarjajo zlasti nekateri geografi pa tudi drugi. S topoklimatskimi vidiki mrazišč so se tako ukvarjali Gams (1972), Ogrin D. in Ogrin M. (2005), Ogrin M. (2007), Ogrin D. in sod. (2007), Ogrin M. in sod. (2006), Trošt (2008), Dovečar in sod. (2009), Ortar in sod. (2010), z vplivi topoklime na prirast vegetacije pa Ogrin D. in Krevs (1995). A te raziskave se ne lotevajo problematike padavin in njihovih lastnosti. Ogrin D. s sodelavci (2013) je v študiji o podnebju Gorenjske izpostavil večjo količino padavin v zatrepih alpskih dolin, kar je eden od pogojev za pojav znižane meje sneženja. Pojav znižane meje sneženja je v grobem poznan zlasti v krogu meteorologov in ostalih poznavalcev vremena. V okviru Slovenskega meteorološkega foruma, ki združuje vremenske strokovnjake in ljubitelje vremena, je ta pojav prepoznan kot pomemben dejavnik gorske klime, a kot že napisano, temeljite proučitve tega pojava v Sloveniji ni opravil še nihče.

Splošno znano pa je, da zlasti na območju Bohinja in v Gornjesavski dolini ob specifičnih padavinskih dogodkih pogosto sneži bistveno nižje kot drugje po Sloveniji. Čeprav so splošne značilnosti tega pojava poznane, je njegova napovedljivost zelo negotova in zahteva poleg poznavanja atmosferskih pogojev tudi precej lokalnih izkušenj meteorologa (Unterstrasser, Zängl, 2006). Ker pojav v slovenskih gorskih pokrajinah še ni bil proučevan, smo se lotili raziskave, ki se posveča značilnostim tega pojava na primeru doline Planice in nasproti ležečega pobočja Peči (Tromeje) v Zahodnih Karavankah v zimi 2014/2015.

\section{POJAV ZNIŽANE MEJE SNEŽENJA}

Meja sneženja je odvisna od več dejavnikov in v bolj kompleksnem terenu je napoved teh dejavnikov lahko problematična oziroma nezanesljiva. Ob padavinah, kjer ne prihaja 
do tople ali hladne advekcije, je pogosto pričakovano, da se temperaturne razmere bistveno ne spreminjajo in praksa pokaže, da je temu pogosto tudi tako. Poznamo pa primere, ko nenadna ohladitev povzroči spust meje sneženja brez menjave zračne mase in preseneti tako meteorologe kot seveda vse ostale. Taki pojavi so lahko zelo intenzivni in v nekaj urah lahko po nižinah nepričakovano pade tudi do $30 \mathrm{~cm}$ snega. Znanih je kar nekaj primerov. Jaffe (1967) opisuje drastično spremembo vremena v Innsbrucku (580 m n. v.) 8. junija 1956, ko je dan potem, ko so namerili $27^{\circ} \mathrm{C}$, zapadlo $15 \mathrm{~cm}$ snega. Ničta izoterma je bila na ta dan v predgorju Severnih Alp na 1200-1500 m. Kot primer iz Slovenije navajamo dogajanje v začetku druge dekade decembra 2008. Od 10. do 12. decembra 2008 je po Sloveniji večinoma deževalo z mejo sneženja, razen ob začetku padavin, nad $1000 \mathrm{~m}$, medtem ko je v Gornjesavski dolini, zlasti od Kranjske Gore navzgor, praktično ves čas snežilo oziroma močno snežilo in v Ratečah so dobili 11. in 12. decembra vsak dan $53 \mathrm{~cm}$ novega snega (ARSO ..., 2016), pri čemer je šlo za južno zimsko vreme s toplo advekcijo in se je zračna masa nad Slovenijo od začetka padavin ogrela. V naši raziskavi smo $\mathrm{V}$ fazi spoznavanja tega pojava v Sloveniji poznavalce vremena povprašali tudi po njihovih izkušnjah z nepričakovano znižano mejo sneženja, saj si mnogi take dogodke večinoma zapomnijo. »10. 3. 2003 je prišlo do pojava, ko sem šel z vlakom iz Ljubljane v Sežano. Vremenska napoved je napovedovala sneženje do $800 \mathrm{~m}$ nadmorske višine. V Ljubljani je bilo $5{ }^{\circ} \mathrm{C}$ in je padal dež, na Brezovici se je dež mešal s snegom, na Verdu (400 m n. v.) pa je samo še snežilo. Po tleh je bilo pobeljeno vse do Postojne, od Postojne dalje pa ni več snežilo. Lisca na 950 m nadmorske višine je imela takrat $3{ }^{\circ} \mathrm{C}$ « (Gustinčič, 2015). »En primer, ki ga poznam že od otroštva, je ZMS v dolini Zadnje Sore. Sicer sem bil le nekajkrat tam točno v času ZMS in na termometru v avtu videl, kako je temperatura med vožnjo padala hitreje, kot je naraščala nadmorska višina. Tam je snežilo, le malo stran pa kljub večji nadmorski višini deževalo« (Ortar, 2015). »V spomin se mi je najbolj vtisnil 18. 10. 1992 v Grosupljem. To je bilo eno najzgodnejših sneženj, padavine so bile takrat zelo močne. V spominu pa mi je dobro ostal tudi 30. 5. 2006 v Lužarjih« (Sinjur, 2015).

Vidimo torej, da gre pri pojavu znižane meje sneženja za hiter padec temperature na območju padavin, ki je nepričakovan, saj ni posledica menjave zračne mase. V Sloveniji je velika večina padavin na samem začetku, ko nastajajo v oblakih, v obliki snega, ne glede na letni čas. Te padavine nastajajo nad $2000 \mathrm{~m}$ in od tam padajo proti tlom. Če je temperatura zraka vse do tal ves čas pod lediščem, potem sneži vse do tal. Če pa se v atmosferi pojavi plast zraka, ki je toplejša od ledišča, kar je pogost pojav, se snežinke začnejo taliti in od tam, kjer se stalijo vse snežinke, proti tlom samo še dežuje. Ko se trdne padavine talijo s toploto iz okolice, se ta toplejša plast ozračja prične ohlajati. Ta proces taljenja lahko ohladi to plast vse do $0{ }^{\circ} \mathrm{C}$, nato pa se proces taljenja v tej plasti ustavi, taljenje pa se prestavi nižje k tlom. Ustvari se pas ničte izoterme, ki pa ne seže vedno do tal (Kain in sod., 2000). Območje izotermije lahko v ekstremnih primerih doseže celo debelino 3 km (Stewart 1992), običajno pa precej manj, okoli 1 km ali manj (Kain in sod., 2000). Za ohlajanje okoliškega zraka je izjemnega pomena latentna toplota. Da preide led oziroma sneg v tekočo obliko, mu mora biti dodana energija zato, da gre led iz višje v nižje urejeno strukturo. Da se led stali ali pa voda izhlapi, je potrebno vzeti energijo iz okolice, da lahko led ali voda preideta v nižje urejeno obliko. Energija je potrebna zato, 
da oslabi individualne vodikove vezi med vodnimi molekulami. Ko se voda giblje iz višjega v nižje stanje urejenosti, bo okoliškemu zraku odvzeta energija. Trije procesi, ki okoliškemu zraku odvzamejo energijo, so izhlapevanje, taljenje in sublimacija (prehod iz trdnega stanja v plinasto). Ko pa voda prehaja iz nižjega v višje urejeno stanje, bo okoliškemu zraku energija dodana. To se imenuje sproščanje latentne toplote. Trije procesi, ki dodajo energijo okoliškemu zraku, so kondenzacija, zmrzovanje in depozicija (prehod iz plinastega stanja v trdno) (Haby, 2015).

Slika 1: Prehod iz močnega deževja v sneženje pri tleh zaradi absorbcije latentne toplote tekom taljenja snežink.

Figure 1: Transition from heavy rain to snow close to the valley bottom due to absorption of latent heat during melting of snowflakes.

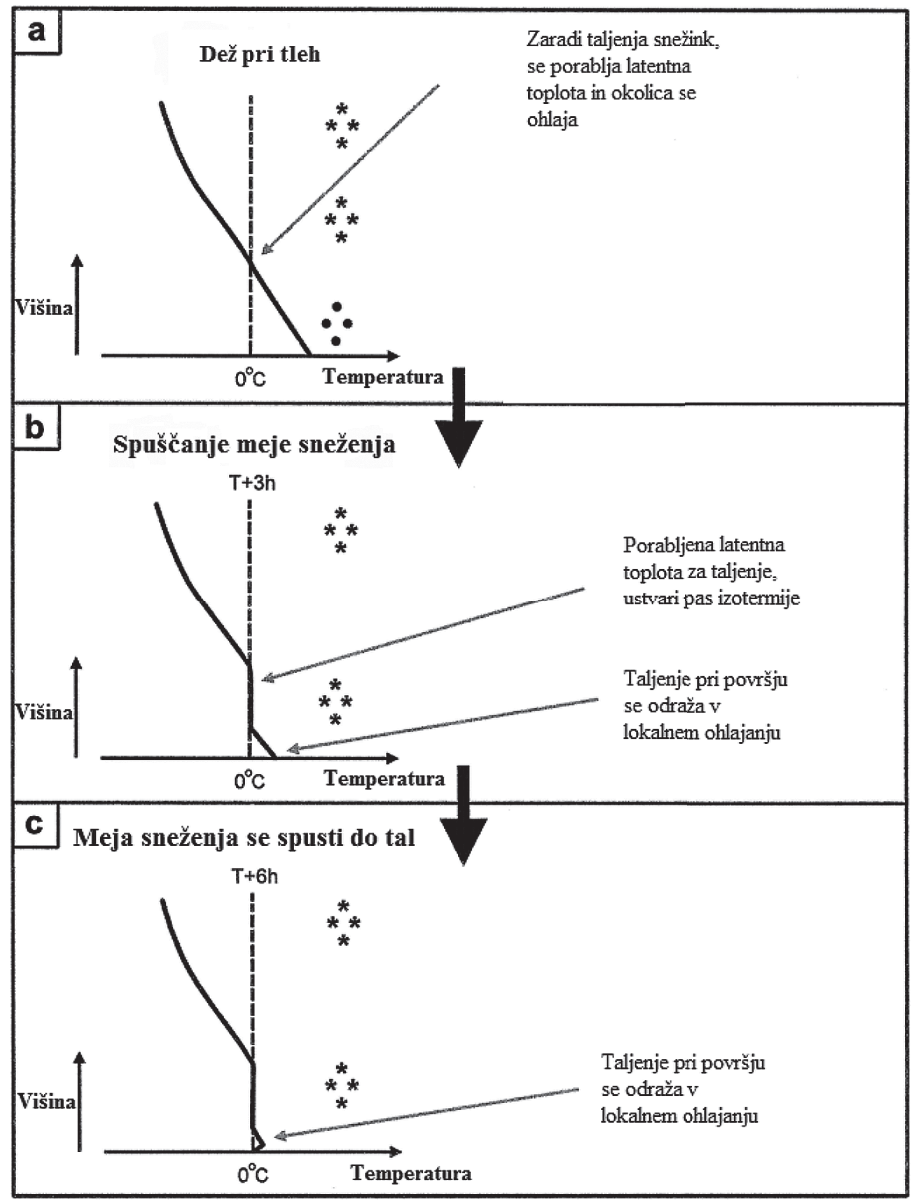

Vir/Source: Lackmann, 2002, str. 1018. 
Ta proces je torej prisoten vedno, kadar pri tleh dežuje, višje zgoraj pa sneži. Ni pa res, da je vedno prisotna močna ohladitev. Po mnenju Velkavrha (2015) so za pojav znižane meje sneženja ključnega pomena intenzivne padavine, Kain in sodelavci (2000) pa navedejo naslednje pogoje:

- Advekcija pri tleh je šibka. Ker je taljenje padavin za temperaturo zraka v stolpcu padavin drugotnega pomena $\mathrm{v}$ primerjavi $\mathrm{z}$ adiabatnimi in diabatnimi procesi, mora biti advekcija šibka, sicer v stolpec padavin priteka nov, toplejši zrak, ki prepreči ohladitev zraka v območju padavin.

- Zmerne do močne padavine trajajo nekaj ur. Približno velja, da je učinek ohlajanja sorazmeren s količino padavin, ohlajanje je najbolj izrazito tam, kjer je intenziteta največja.

- Temperature na površju so ob začetku dogodka navadno nekaj stopinj nad ničlo. $\mathrm{Ob}$ rahlih padavinah je učinek znižane meje sneženja majhen oziroma ga ni, razen če so temperature ob začetku malo nad $0{ }^{\circ} \mathrm{C}$. Topleje kot je ob začetku, močnejše morajo biti padavine za znižano mejo sneženja do tal.

V začetku pojava padavin je ohlajanje zraka lahko dodatno pospešeno zaradi izhlapevanja padavin, saj zrak navadno še ni nasičen z vlago (Unterstrasser, Zängl, 2006; Kain in sod., 2000). Izhlapevanje porablja ogromno latentne toplote $(2,25 \mathrm{MJ} / \mathrm{K})$ in je $\mathrm{z}$ energetskega stališča približno šestkrat večji porabnik toplote kot taljenje $(334 \mathrm{~kJ} / \mathrm{kg})$, vendar navadno ta pojav traja precej manj časa, saj se zračna masa v času padavin največkrat hitro nasiči in izhlapevanje se ustavi. Hkrati pa padavine ne izhlapijo v celoti in jih večji del prileti do tal, pri taljenju v procesu znižane meje sneženja pa se stalijo vse snežinke. Jaffe (1967) in Steinacker (1983) navajata, da so pogoji za pojav znižane meje sneženja še posebno ugodni v globokih alpskih dolinah, kjer gorske verige slabijo vetrove v spodnjem delu atmosfere, res pa je, da se ta pojav lahko pojavi tudi nad ravninami, le da je tam manj pogost. To dejstvo nam pojasni, zakaj je tudi v Sloveniji ta pojav najpogosteje opažen v Bohinju in Gornjesavski dolini oziroma v gorskih pokrajinah nasploh.

\section{MERITVE}

Ugotavljanja pojava znižane meje sneženja smo se lotili s proučevanjem temperaturnih razmer v času zimskih padavinskih dogodkov. Za območje meritev smo si izbrali profil šestih merilnih postaj, ki smo jih postavili po dolini Planice in po pobočju Peči v Zahodnih Karavankah na skrajnem severozahodu Slovenije. Kot najnižja temperaturna postaja pa nam je služila meteorološka postaja ARSO v Ratečah. Pojav znižane meje sneženja s pomočjo temperaturnih razmer ugotovimo, če v času padavinskega dogodka najprej dežuje v vsaj delu proučevanega profila, potem pa se s časom po profilu oblikuje vse debelejša plast s temperaturo $0{ }^{\circ} \mathrm{C}$ ali malo nad $0{ }^{\circ} \mathrm{C}$. Pri tem nas je zanimala tudi dinamika vzpostavitve izotermne plasti in njena simetričnost oziroma ali se meja sneženja po profilu spušča enakomerno po nadmorski višini ali pa je ničta izoterma nagnjena.

Izbira lokacije merilnih postaj je temeljila na podlagi nadmorske višine. Na pobočju Peči in po dolini Planice smo merilna mesta izbrali na podobnih nadmorskih višinah. 
Postaja K1 je bila na nadmorski višini 1000 m, postaja P1 na nadmorski višini 990 m, postaja K2 na nadmorski višini 1234 m, postaja P2 na nadmorski višini $1200 \mathrm{~m}$, postaja K3 na nadmorski višini $1415 \mathrm{~m}$ in postaja P3 na nadmorski višini 1390 m.

Slika 2: Lokacije merilnih postaj.

Figure 2: Location of temperature stations.

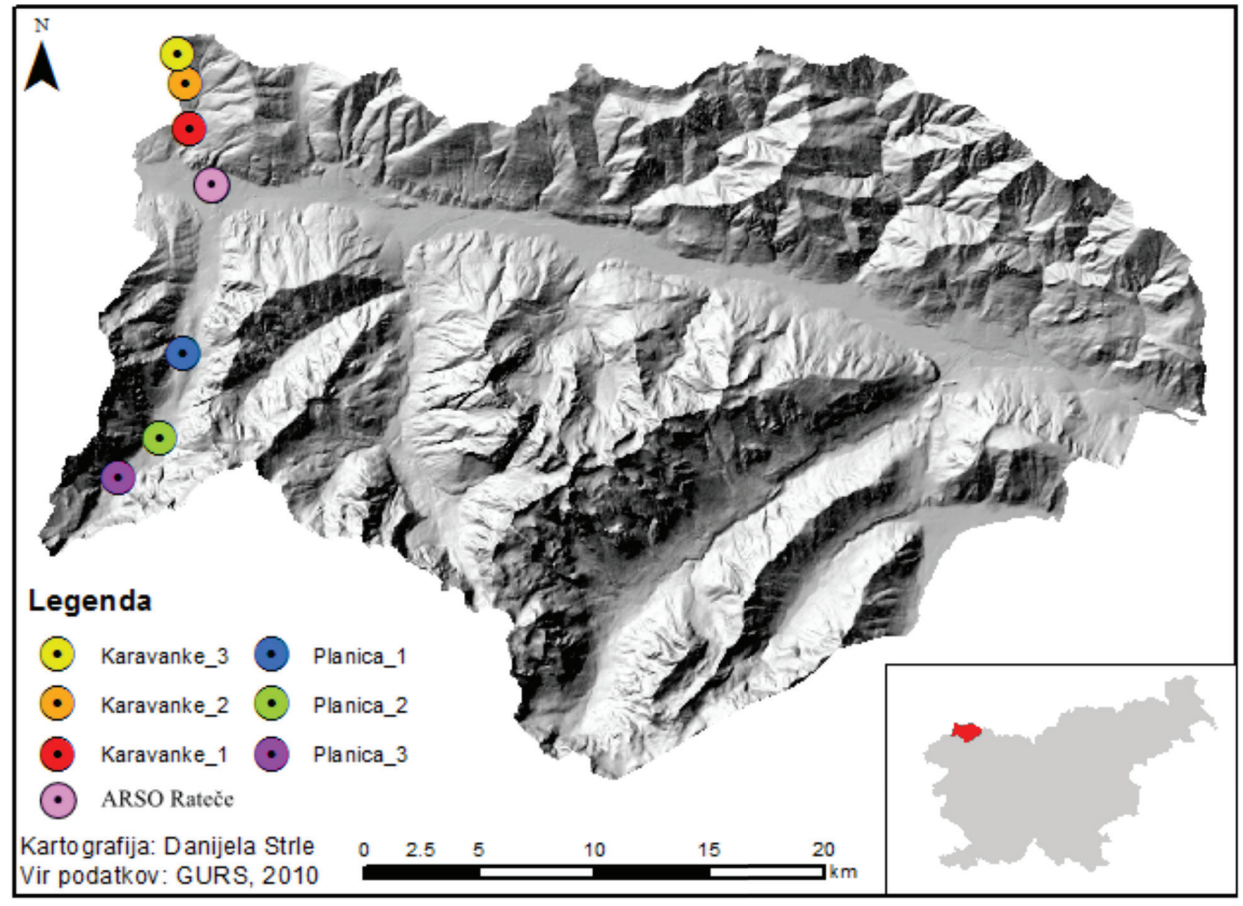

Slika 3: Višinski profil proučevanega območja.

Figure 3: Elevation profile of the studied area.

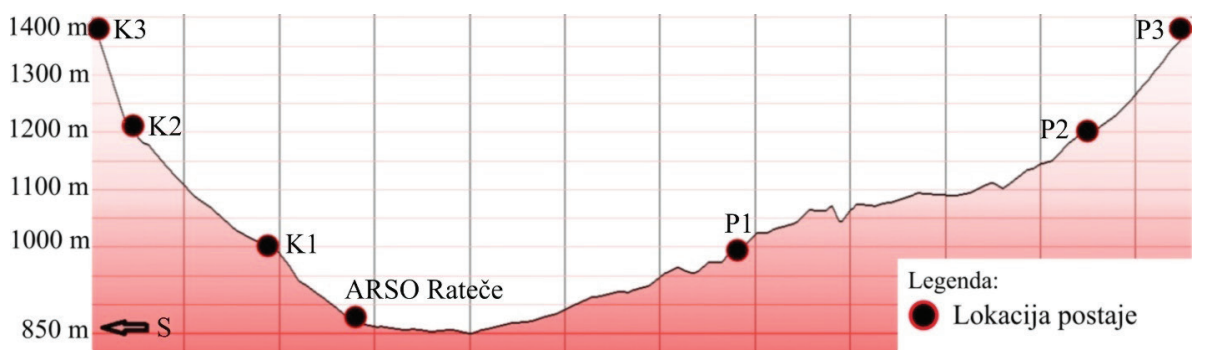

Temperaturo smo merili s pomočjo i-gumbka, na vsakem merilnem mestu enega. Igumbek je digitalni termometer, ki smo ga postavili v radiacijski zaklon, saj predstavlja 
imitacijo vremenske hiške. V radiacijskem zaklonu je digitalni termometer zavarovan pred vremenskimi vplivi, ki bi vplivali na točnost izmerjenih podatkov. Ker so nas zanimale le razmere med padavinami, ko ni direktnega Sončevega obsevanja, je vpliv njihove mikrolege na temperaturne podatke zanemarljiv, zato smo jih pritrdili kar na debla dreves. Vseh šest i-gumbkov smo nastavili na ločljivost $0,1{ }^{\circ} \mathrm{C}$, izmerjeno temperaturo pa so zabeležili vsakih 15 minut. Merili so v zimskem UTC+1 času od 7. 12. 2014 pa vse do 24. 4. 2015. Zaradi nastavitve termometrov na visoko ločljivost in 15-minutnega intervala meritev temperature je bilo treba tekom meritev na približno 42 dni na teren, zbrati zabeležene podatke ter ponovno nastaviti registratorje temperature.

Slika 4: Merilna mesta, ki si sledijo po vrstnem redu od leve proti desni: Planica 3, Planica 2, Planica 1, Karavanke 3, Karavanke 2 in Karavanke 1 (foto: D. Strle, 2014).

Figure 4: Temperature stations (from left to right): Planica 2, Planica 1, Karavanke 3, Karavanke 2 in Karavanke 1 (photo: D. Strle, 2014).

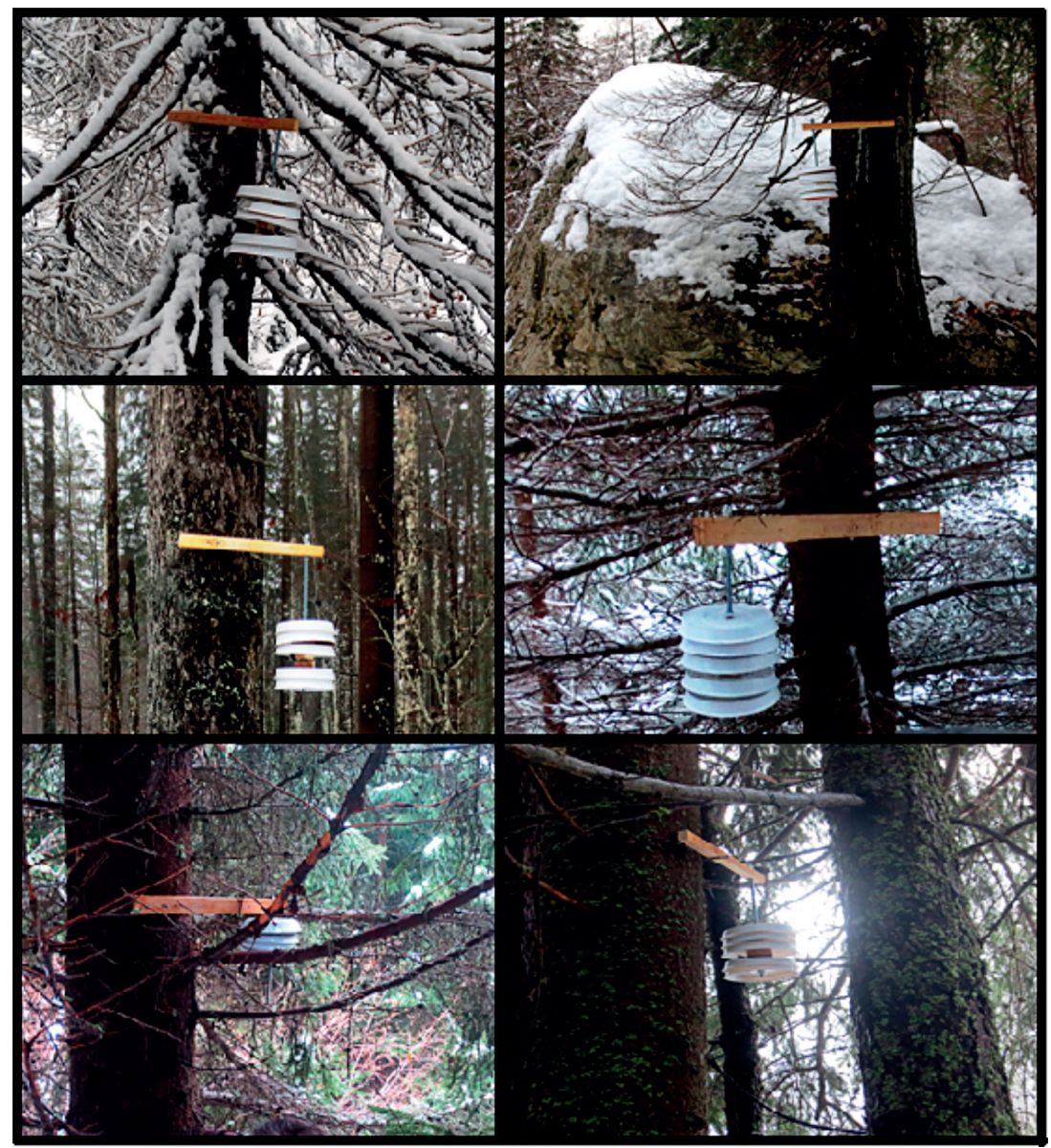




\section{REZULTATI}

Meritvam temperature na proučevanem območju je sledila analiza pridobljenih podatkov. Analizirali smo podatke za obdobje, ko smo domnevali, da se je zgodil pojav znižane meje sneženja. Sam pojav je močno odvisen tudi od trajanja in intenzivnosti padavin, zato smo za ta dan proučili tudi podatke o padavinah, ki so bile izmerjene na samodejni postaji ARSO Rateče, ki leži na nadmorski višini 864 m med dolino Planice in pobočjem Peči.

$\mathrm{V}$ analizo temperature smo zajeli podatke tudi nekaj ur pred pojavom, prav tako tudi nekaj ur po tem, ko se je končal, vključili pa smo tudi podatke iz postaj v bližini. Zelo pomembno je bilo primerjati potek temperature med postajama na podobni nadmorski višini, torej Planica 1 in Karavanke 1, Planica 2 in Karavanke 2 ter Planica 3 in Karavanke 3. Poleg omenjene primerjave je bila opravljena tudi primerjava temperature $\mathrm{z}$ nadmorsko višino. V zvezi s padavinami nas je zanimal tudi potek temperature v odvisnosti od njihove intenzitete in trajanja. Seveda bi bil vzrok za znižanje meje sneženja lahko tudi v hladni advekciji in ne mehanizmu taljenja snežink ter intenzivnosti padavin. Zato smo za proučevano obdobje preverili tudi potek temperature in hitrost vetra na okoliških postajah ARSO.

Zima 2014/2015 je bila zelo skromna s situacijami, ki so nakazovale pojav znižane meje sneženja na proučevanem območju. Pravega primera z intenzivnimi padavinami in izrazito ohladitvijo zaradi padavin niti ni bilo. Kljub vsemu pa se je že po koncu koledarske zime v noči s 25. na 26. marec 2015 ob prehodu neizrazite vremenske motnje, ko se je zračna masa nad nami celo malo ogrela, na proučevanem območju meja sneženja nenadejano spustila do dna doline.

\section{I Vremenske razmere 25. in 26.3.20I 5}

Najprej poglejmo uradno vremensko napoved ARSO za gorski svet dne 25. 3. 2015 :

"Danes bo oblačno, zjutraj ponekod v visokogorju še delno jasno. Sredi dneva in popoldne bo začelo rahlo deževati, nad približno 1600 metri pa snežiti. Pihal bo rahel do zmeren jugovzhodni veter. Na višini 1500 metrov bo temperatura približno 3, na višini 2500 metrov pa -4 stopinje Celzija.

Jutri bo oblačno s padavinami, popoldne zlasti krajevnimi plohami. Meja sneženja bo med 1300 in 1600 m. Pihal bo rahel veter južnih smeri. Na višini 1500 metrov bo temperatura približno 3, na višini 2500 metrov pa -2 stopinji Celzija.« (Vremenska napoved v preteklosti, 2015).

Vidimo torej, da je vremenska napoved omenjala približno enake temperature za obdobje poslabšanja. Povečana konvektivna aktivnost nakazuje nekoliko hladnejše razmere v višinah po prehodu motnje, a ohladitev v spodnjih plasteh ni bila predvidena.

Preglednice 1, 2, 3 in 4 kažejo, da se s 25. na 26. marec zagotovo ni ohladilo, ne na višini okoli 2500 m niti ne nižje, kvečjemu je šlo za manjšo otoplitev. Torej lahko trdimo, da v padavinskem dogodku 25. in 26. marca ni šlo za hladno advekcijo. A poglejmo, kaj se je ponoči na 26. marec dogajalo na naših merilnih postajah in v Ratečah. Na navedenih postajah je padlo od 41 do $65 \mathrm{~mm}$ padavin, le v Ratečah opazno manj, in sicer $28 \mathrm{~mm}$. 
Preglednica 1: Vremenske razmere na Kredarici $(2514 \mathrm{~m})$ 25. in 26. marca 2015. Table 1: Weather conditions on Kredarica $(2514$ m) on 25 and 26 March 2015.

\begin{tabular}{|c|c|c|c|c|c|c|}
\hline $\begin{array}{c}\text { Kredarica } \\
(\mathbf{2 5 1 4} \mathbf{~ m )}\end{array}$ & Tpovp. $\left({ }^{\circ} \mathbf{C}\right)$ & Tmaks. $\left({ }^{\mathbf{C}} \mathbf{C}\right)$ & Tmin. $\left({ }^{\circ} \mathbf{C}\right)$ & $\begin{array}{c}\text { Višina } \\
\text { snežne odeje } \\
(\mathbf{c m})\end{array}$ & $\begin{array}{c}\text { Višina } \\
\text { novega } \\
\text { snega (cm) }\end{array}$ & $\begin{array}{c}\text { Višina } \\
\text { padavin } \\
(\mathbf{m m})\end{array}$ \\
\hline 25.3 .2015 & $-4,3$ & $-2,9$ & $-5,2$ & 180 & 0 & 0 \\
\hline 26.3 .2015 & $-2,4$ & $-1,8$ & $-4,2$ & 220 & 43 & 41 \\
\hline
\end{tabular}

Vir: ARSO, arhiv podatkov, 2016.

Preglednica 2: Vremenske razmere na Voglu (1535 m) 25. in 26. marca 2015.

Table 2: Weather conditions on Vogel (1535 m) on 25 and 26 March 2015.

\begin{tabular}{|c|c|c|c|c|c|c|}
\hline $\begin{array}{c}\text { Vogel } \\
(\mathbf{1 5 3 5} \mathbf{~ m})\end{array}$ & Tpovp. $\left({ }^{\circ} \mathbf{C}\right)$ & Tmaks. $\left({ }^{\circ} \mathbf{C}\right)$ & Tmin. $\left({ }^{\circ} \mathbf{C}\right)$ & $\begin{array}{c}\text { Višina } \\
\text { snežne odeje } \\
(\mathbf{c m})\end{array}$ & $\begin{array}{c}\text { Višina } \\
\text { novega } \\
\text { snega (cm) }\end{array}$ & $\begin{array}{c}\text { Višina } \\
\text { padavin } \\
(\mathbf{m m})\end{array}$ \\
\hline 25.3 .2015 & 0,5 & 3 & $-1,2$ & 95 & 0 & 0 \\
\hline 26.3 .2015 & 3 & 4 & $-0,2$ & 100 & 10 & 65 \\
\hline
\end{tabular}

Vir: ARSO, arhiv podatkov, 2016.

Preglednica 3: Vremenske razmere v Ratečah (864 m) 25. in 26. marca 2015.

Table 3: Weather conditions in Rateče $(864 \mathrm{~m})$ on 25 and 26 March 2015.

\begin{tabular}{|c|c|c|c|c|c|c|}
\hline $\begin{array}{c}\text { Rateče } \\
(\mathbf{8 6 4} \mathbf{~ m})\end{array}$ & Tpovp. $\left({ }^{\circ} \mathbf{C}\right)$ & Tmaks. $\left({ }^{\circ} \mathbf{C}\right)$ & Tmin. $\left({ }^{\circ} \mathbf{C}\right)$ & $\begin{array}{c}\text { Višina } \\
\text { snežne odeje } \\
(\mathbf{c m})\end{array}$ & $\begin{array}{c}\text { Višina } \\
\text { novega } \\
\text { snega (cm) }\end{array}$ & $\begin{array}{c}\text { Višina } \\
\text { padavin } \\
(\mathbf{m m})\end{array}$ \\
\hline 25.3 .2015 & 3,1 & 7,5 & $-1,4$ & 0 & 0 & 0 \\
\hline 26.3 .2015 & 4,7 & 6,6 & 1,6 & 0 & 0 & 28,1 \\
\hline
\end{tabular}

Vir: ARSO, arhiv podatkov, 2016.

Preglednica 4: Vremenske razmere v Lescah (575 m) 25. in 26. marca 2015. Table 4: Weather conditions in Lesce $(575 \mathrm{~m})$ on 25 and 26 March 2015.

\begin{tabular}{|c|c|c|c|c|c|c|}
\hline $\begin{array}{c}\text { Lesce } \\
\mathbf{( 5 7 5} \mathbf{~ m})\end{array}$ & Tpovp. $\left({ }^{\circ} \mathbf{C}\right)$ & Tmaks. $\left({ }^{\circ} \mathbf{C}\right)$ & Tmin. $\left({ }^{\circ} \mathbf{C}\right)$ & $\begin{array}{c}\text { Višina } \\
\text { snežne odeje } \\
(\mathbf{c m})\end{array}$ & $\begin{array}{c}\text { Višina } \\
\text { novega } \\
\text { snega (cm) }\end{array}$ & $\begin{array}{c}\text { Višina } \\
\text { padavin } \\
(\mathbf{m m})\end{array}$ \\
\hline 25.3 .2015 & 6,1 & 8,3 & 1,5 & 0 & 0 & 0 \\
\hline 26.3 .2015 & 7,4 & 9 & 4,9 & 0 & 0 & 52 \\
\hline
\end{tabular}

Vir: ARSO, arhiv podatkov, 2016. 
Slika 5: Potek temperature in hitrosti vetra na postaji ARSO Kredarica 25. in 26. marca 2015. Figure 5: Temperatures and wind speed at the Kredarica meteorological station on 25 and 26 March 2016.

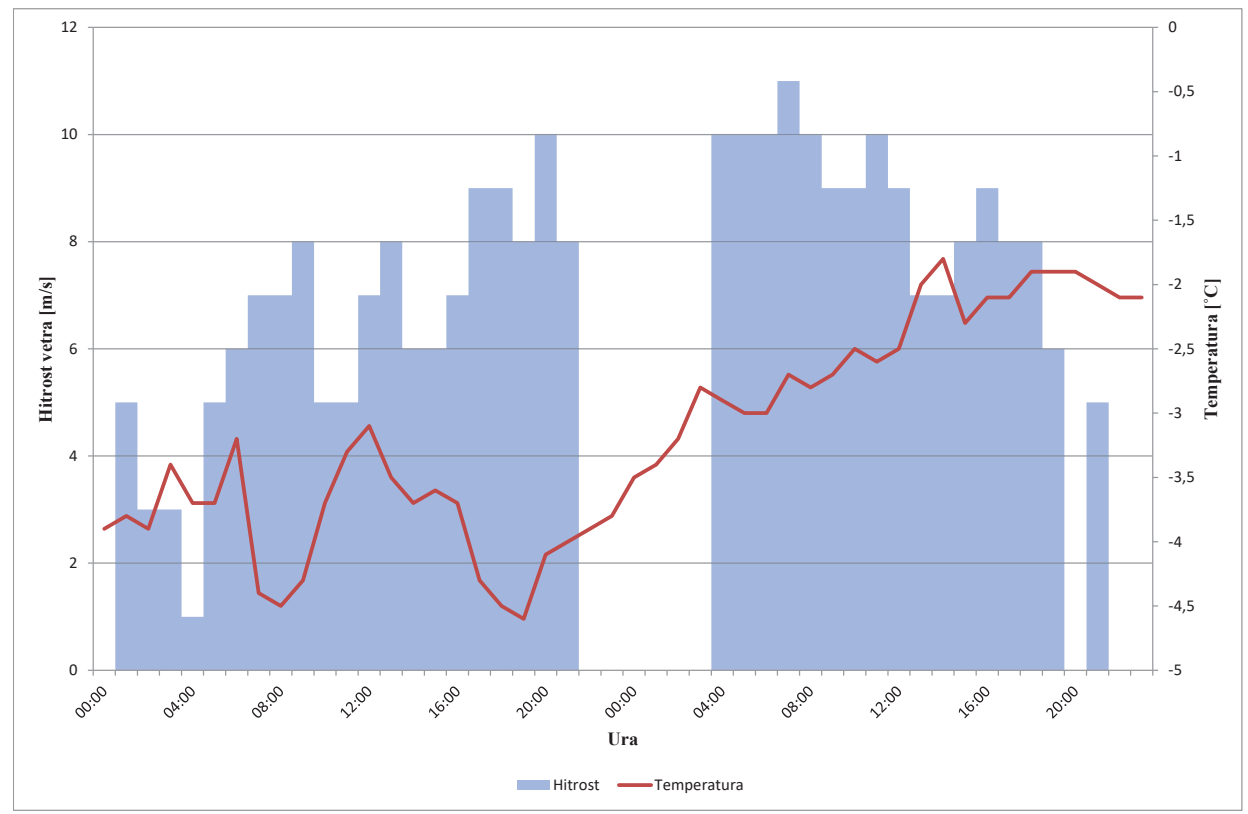

Vir podatkov/Data source: OGIMET, 2015.

Tudi iz urnih podatkov o temperaturi, hitrosti in smeri vetra na Kredarici lahko vidimo, da nad območjem ni bilo hladne advekcije. 
Slika 6: Polurni podatki o količini padavin v Ratečah v času pojava znižane meje sneženja 25. in 26. marca 2015.

Figure 6: Data on half-hour precipitation in Rateče during the lowered snowline event on 25 and 26 March 2015.

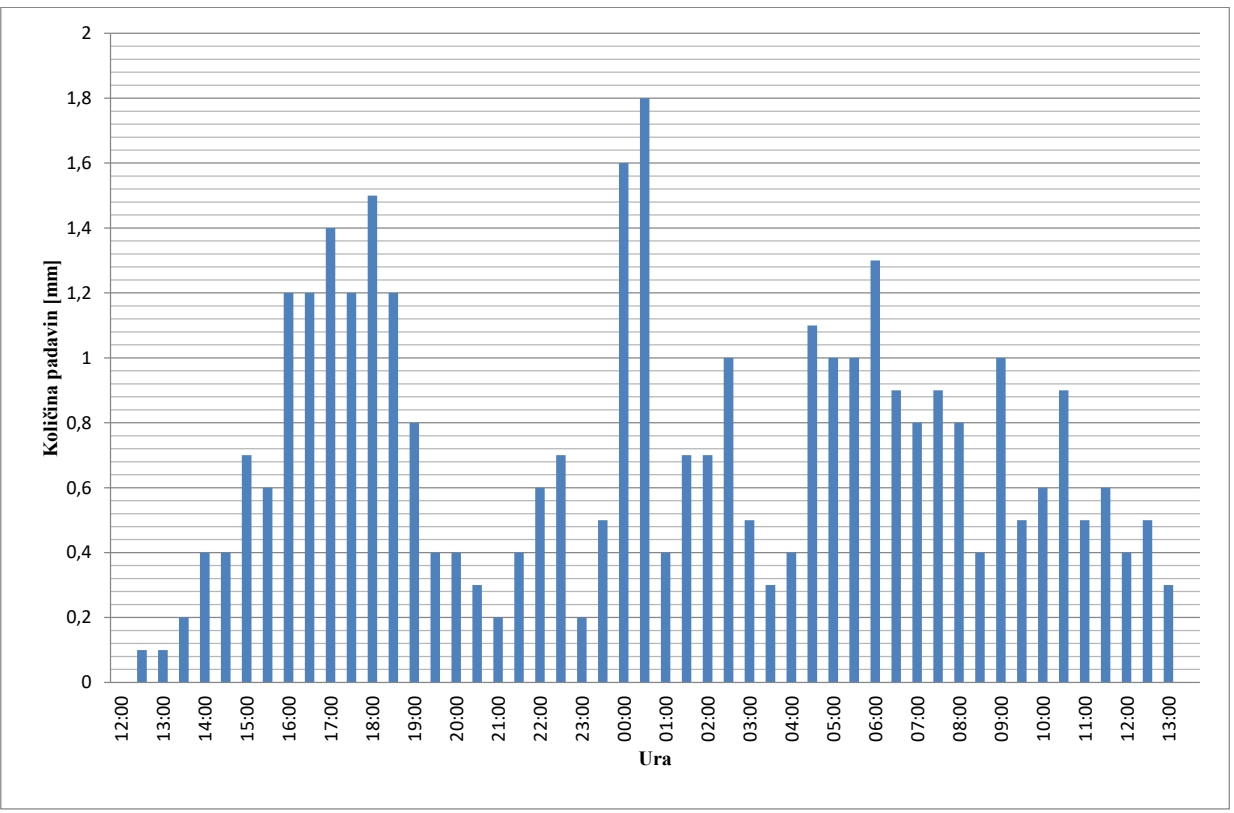

Vir/Source: ARSO, arhiv podatkov, 2016.

Na postaji v Ratečah je začelo deževati dan pred pojavom. Sprva so bile padavine šibke, nato pa so se v popoldanskem času nekoliko okrepile, a ne zelo. Tej okrepitvi je $\mathrm{V}$ večernih urah sledil padec intenzivnosti. V času med 23.30 in 1.00 je intenziteta padavin ponovno narasla. Z 0,2 mm padavin na pol ure so se okrepile na 1,8 $\mathrm{mm}$. Obdobju obilnejših padavin je sledil ponoven padec intenzitete, vse dokler niso malo po poldnevu povsem ponehale.

A izkazalo se je, da je kljub vremenski napovedi, da bo meja sneženja med 1300 in 1600 m, na proučevanem območju v noči s 25. na 26. marec snežilo nižje. Sicer je šlo za neizrazit in razmeroma kratkotrajen spust meje sneženja, a dovolj, da je bila zjutraj dolina Planice pri skakalnicah pobeljena. 
Slika 7: Potek temperature in padavin od 25. 3. 2015 ob 16. uri do 26. 3. 2015 ob 13. uri. Figure 7: Temperature and precipitation from 25 March 2016 at 16:00 to 26 March 2015 at 13:00.

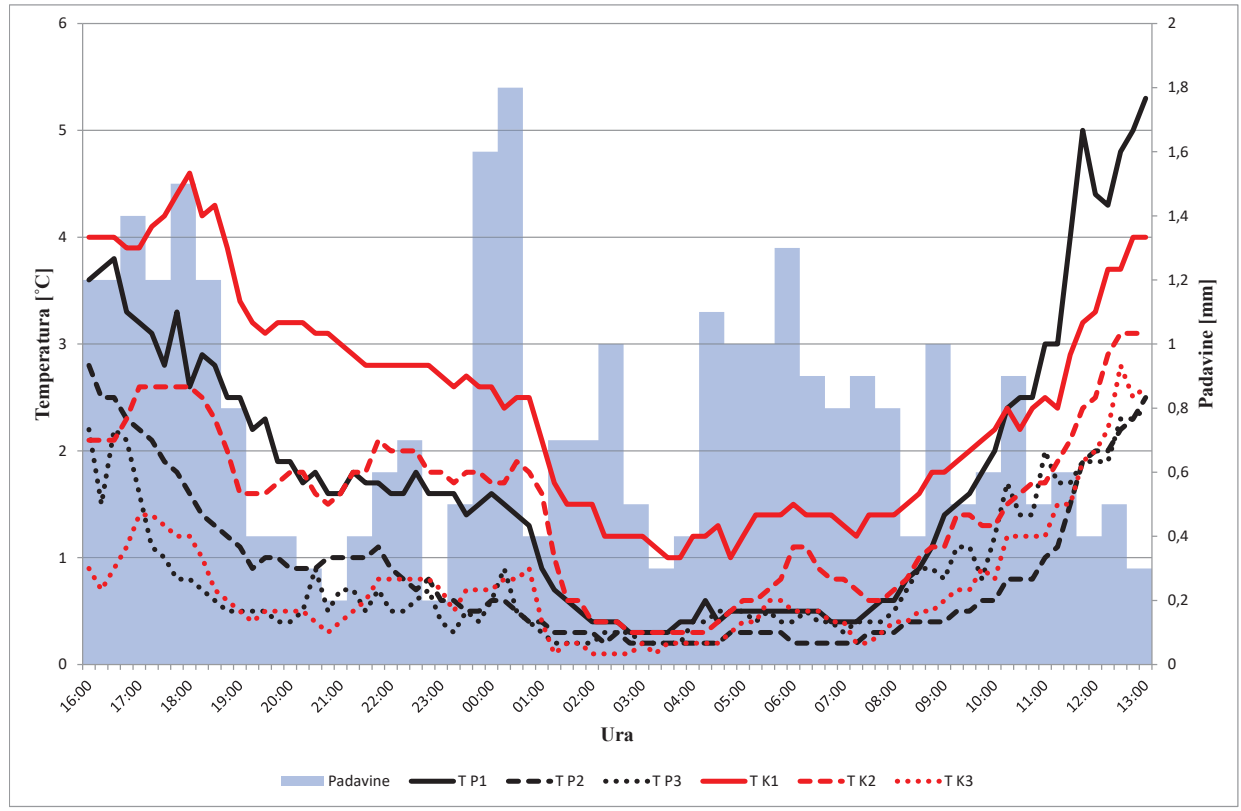

Vir padavinskih podatkov/Precipitation data source: ARSO, arhiv podatkov, 2016.

Iz temperaturnega profila (slika 7) smo prišli do naslednjih ugotovitev:

- Temperatura je na vseh šestih merilnih mestih od popoldneva počasi padala, po obdobju intenzivnejših padavin pa je bil njen padec veliko izrazitejši in takrat se je v dolini Planice izoblikoval skoraj popoln pas izotermije s temperaturo nekaj desetink nad $0{ }^{\circ} \mathrm{C}$, medtem ko je bil dogodek na pobočju Peči manj izrazit.

- Na pobočju Peči je bil pojav znižane meje sneženja manj izrazit kot v dolini Planice. Vzrok za to bi lahko iskali v močnejših padavinah v dolini Planice kot na pobočju Peči ter bolj izrazitem zastajanju hladnega zraka v dolini Planice zaradi ugodnejše reliefne izoblikovanosti.

- Poteki temperature v dolini Planice (P1, P2 in P3) kažejo na to, da se je ohlajanje tam začelo prej kot na pobočju Peči (K1, K2 in K3), kar verjetno nakazuje na bolj intenzivne padavine in verjetno tudi kopičenje hladnega zraka v zatrepu doline Planice.

- Intenziteta ohladitve s spuščanjem po nadmorski višini narašča, kar je v dolini Planice privedlo do skoraj popolne izotermije.

- Najnižja temperatura je v dnu doline Planice nižja kot na enaki nadmorski višini na pobočju Peči.

- Ohladitev tudi po koncu pojava znižane meje sneženja traja dlje v dolini Planice kot na pobočju Peči. Razlog je v zadrževanju jezera hladnega zraka. 
- Temperaturni gradient je pri znižani meji sneženja povsem netipičen, saj ničto izotermo vleče navzdol, proti dnu doline. Pod $0{ }^{\circ} \mathrm{C}$ se ne spusti, saj taleče snežinke okoliškega zraka ne morejo ohladiti pod to temperaturo. Ozračje se zaradi porabljanja latentne toplote lahko ohladi le do $0{ }^{\circ} \mathrm{C}$, nato pa se ta proces ustavi. Na primeru doline Planice je vidno, da je nižanje meje sneženja ustvarilo skoraj popoln pas izotermije, medtem ko je bilo na pobočju Peči to manj izrazito (slika 8).

Slika 8: Višinski profil temperature v času znižane meje sneženja v dolini Planice in na pobočju Peči 26. 3. 2015 ob 0.15, 3.15 in 4.45.

Figure 8: Vertical temperature profile in the time of lowered snow-line in the Planica Valley and on the slopes of Mt. Peč on 26 March 2016 at 00:15, 03:15 and 04:45.
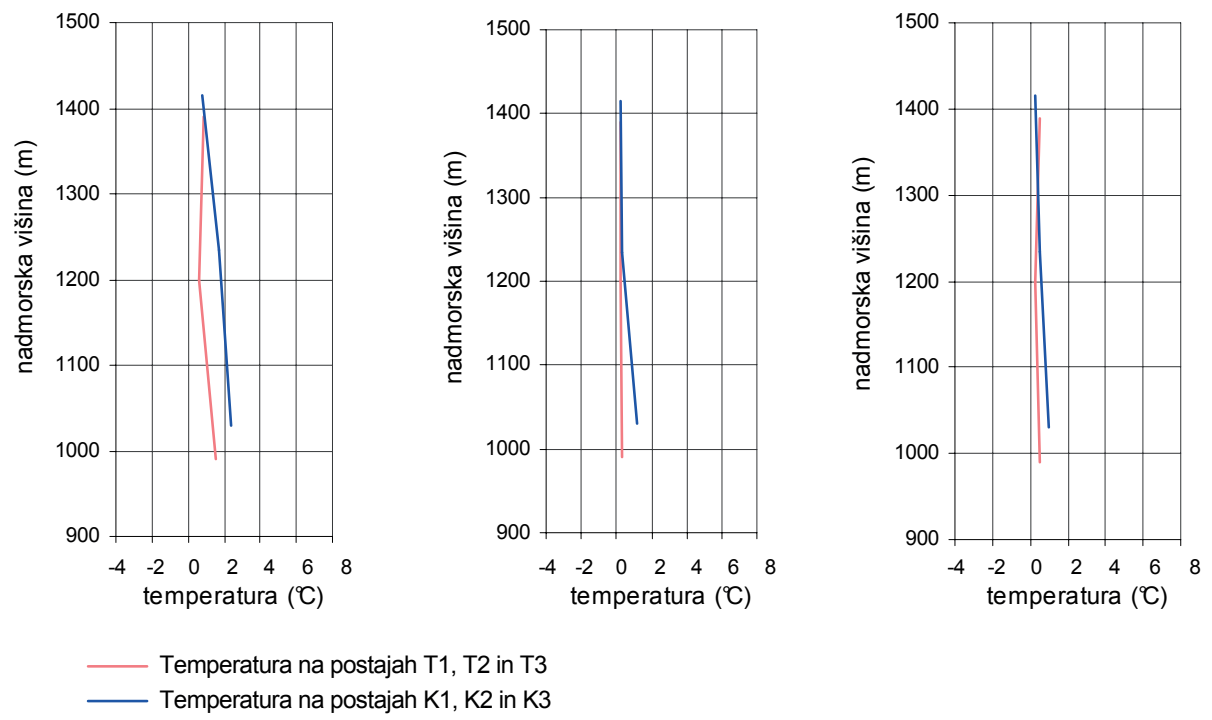

Višinski profil temperature $\mathrm{v}$ času znižane meje sneženja kaže na oblikovanje izotermije v dolini Planice in njen postopen razkroj po koncu pojava znižane meje sneženja. Na pobočju Peči je pojav precej manj izrazit. Torej se jasno vidi, da ohlajanje v dolini Planice in na pobočju Peči ni bilo posledica hladne advekcije, ampak nekoliko močnejših in dalj časa trajajočih padavin. 


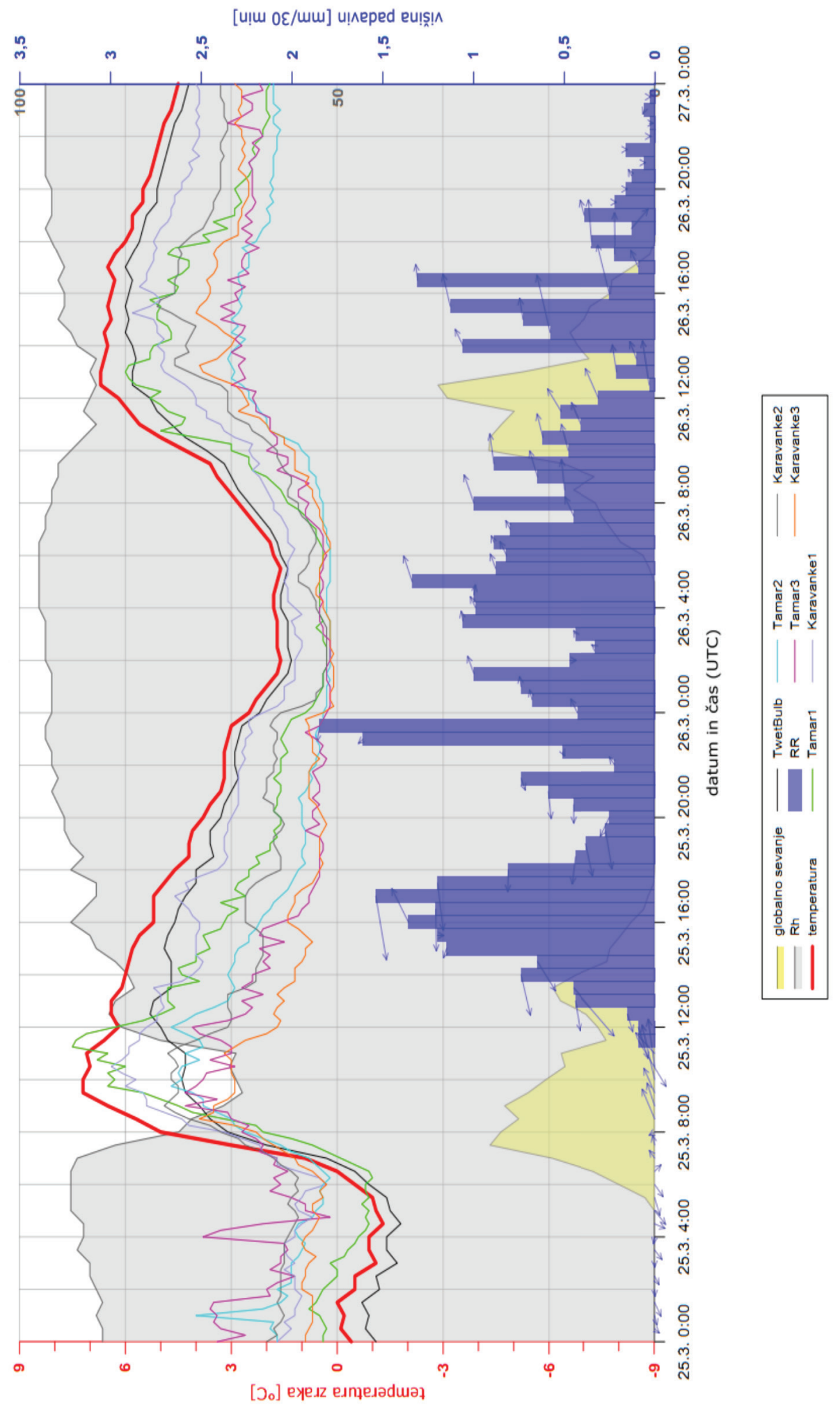


Slika 9 (na prejšnji strani): Potek temperature na šestih merilnih postajah in podatki s samodejne postaje ARSO Rateče 25. in 26. marca 2015.

Figure 9 (opposite): Temperature at 6 weather stations and data for SEA (Slovenian Environment Agency) automatic weather station in Rateče on March 25 and 26, 2015.

Vir podatkov/Data source: ARSO, arhiv podatkov, 2016. Avtor grafa/Author of the graph: Jaka Ortar, 2015

$\mathrm{Na}$ osi $\mathrm{x}$ sta datum in čas prikazana $\mathrm{v}$ univerzalnem koordinatnem času (UTC), podatki $\mathrm{v}$ grafu pa veljajo za zimski UTC +1 čas. Zaradi tega podatki na grafu prehitevajo za eno uro, glede na os x.

Slika 9 nam še enkrat pokaže temperaturne hode, tokrat tudi s temperaturo v Ratečah, ki se je v proučevani noči ustavila na $1,6^{\circ} \mathrm{C}$. Prav v Ratečah nove snežne odeje niti niso beležili. Je pa tanka snežna odeja, kak centimeter ali dva, obležala pri skakalnicah, kar so lepo pokazale spletne kamere zjutraj 26. marca. Z grafom smo želeli prikazati predvsem potek relativne vlage, potek temperature mokrega termometra in hitrost vetra pred, med in po končanem pojavu znižane meje sneženja na dan 26. 3. 2015. Relativna vlaga zraka je takoj po tem, ko so se začele padavine, začela naraščati, saj so padavine začele izhlapevati. Najvišja relativna vlažnost zraka je bila pri tleh dosežena po obdobju najmočnejših padavin, ko je prišlo do pojava znižane meje sneženja in je bila tudi temperatura najnižja. Ko so padavine izhlapevale, se je okoliški zrak zaradi tega procesa ohlajal, a v obdobju največje vlažnosti je izhlapevanje majhno, taljenje pa poteka nemoteno naprej in ohlaja ozračje. Višja kot je bila relativna vlaga zraka, nižja je bila temperatura suhega in mokrega termometra. Temperatura mokrega termometra se je še pred pojavom znižane meje sneženja začela približevati temperaturi suhega termometra in se ji med proučevanim pojavom zelo približala. Bolj ko je bil zrak vlažen (bližje sta si bili temperaturi mokrega in suhega termometra), manj so padavine izhlapevale in bolj so se snežinke talile. Temperatura se je nato začela višati in kasneje je tudi relativna vlažnost zraka začela padati. Po končanem pojavu znižane meje sneženja se je razlika med temperaturama mokrega in suhega termometra začela večati. Pri vetru smo lahko iz grafa razbrali, da je pred pojavom znižane meje sneženja njegova hitrost padla in so bile nekatere izmed najnižjih vrednosti ravno med pojavom. Po končanem pojavu se je veter nekoliko okrepil.

\section{SKLEP}

Čeprav v zimi 2014/2015 na območju Gornjesavske doline ni bil zabeležen niti en izrazit pojav znižane meje sneženja, se je tik pred koncem marca, v noči s 25 . na 26. marec $2015 \mathrm{ob}$ prehodu vremenske motnje vendarle zgodil vsaj neizrazit primer znižane meje sneženja. Z analizo temperatur na okoliških postajah smo dokazali, da kratkotrajna ohladitev na proučevanem območju ni bila posledica hladne advekcije, pač pa pojava padavin, taljenja snežink v območju pod višino ničte izoterme in šibkega vetra v območju ohlajanja. Temperaturne razmere v času dogodka so pokazale izotermijo v dolini Planice, manj izrazita pa je bila na pobočju Peči. Tudi ohlajanje je bilo bolj izrazito na območju doline Planice, reliefna oblikovanost pa je v dolini zadržala hladni zrak dlje tudi po koncu pojava. Bolj izrazito ohlajanje v dolini Planice pripisujemo večji količini padavin proti zatrepu 
doline in lažjemu kopičenju hladnega zraka v zaprti dolini. Kljub uspešni analizi omenjenega pojava znižane meje sneženja ostaja še precej neznank glede splošnih značilnosti tega pojava na proučevanem območju kot tudi primerjave intenzivnosti in pogostnosti pojavov znižane meje sneženja v okoliških dolinah in tudi širše v slovenskih gorskih pokrajinah.

\section{Literatura in viri}

ARSO, arhiv podatkov, 2016. URL: http://meteo.arso.gov.si/met/sl/app/webmet/\#webmet $==8 \mathrm{Sdw}$ 2 bhR2cv0WZ0V2bvEGcw9ydlJWblR3LwVnaz9SYtVmYh9iclFGbt9SaulGdugXbsx3cs9md15WahxXYyNGapZXZ8tHZv1WYp5mOnMHbvZXZulWYnwCchJXYtVGdlJnOn0UQQdSf; (citirano 17. 10. 2016).

Dovečar, M., Sinjur, I., Ogrin, M., Vertačnik, G., 2009. Najnižja temperatura v Sloveniji. Geografski obzornik, 56, 1/2, str. 27-31.

Gams, I., 1972. Prispevek k mikroklimatologiji vrtač in kraških polj. Geografski zbornik, $13,77 \mathrm{str}$.

Gustinčič, M., 2015. Pojav znižane meje sneženja (osebni vir, 27. 3. 2015). Logatec.

Haby, J., 2015. Understanding latent heat. URL: http://www.theweatherprediction.com/ habyhints/19/ (citirano 13. 5. 2015).

Jaffe, A., 1967. Über eine Ursache frühsommerlicher Schneefälle in Talniederungen. 9. Internationale Tagung für Alpine Meteorologie in Brig und Zermatt 14-17. Sept. 1966. Veröffentlichungen der Schweizerischen meteorologischen Zentralanstalt, 4, str. 150-154.

Kain, S. J., Goss, M. S., Baldwin, E. M., 2000. The Melting Effect as a Factor in Precipitation-Type Forecasting. Weather and Forecasting, 15, str. 700-714. URL: http:// www.spc.noaa.gov/publications/goss/kaingoss.pdf (citirano 1. 5. 2015).

Lackmann, M. G., Keeter, K., Lee, G. L., Ek, B. M., 2002. Model Representation of Freezing and Melting Precipitation: Implications for Winter Weather Forecasting. Weather and Forecasting, 17, str. 1016-1033. URL: http://journals.ametsoc.org/doi/ pdf/10.1175/1520-0434(2003)017\%3C1016\%3AMROFAM\%3E2.0.CO\%3B2 (citirano 17. 4. 2015).

OGIMET. URL: http://www.ogimet.com/cgi-bin/gsynres?ind=14008\&lang=en\&deco$\mathrm{ded}=$ yes $\&$ ndays $=2 \&$ ano $=2015 \& \mathrm{mes}=03 \&$ day $=27 \&$ hora $=00($ citirano 12.8 .2015$)$.

Ogrin, D., Ogrin, M., 2005. Predhodno poročilo o raziskovanju minimalnih temperatur v mraziščih pozimi 2004/2005. Dela, 2005, 23, str. 221-233.

Ogrin, D., Ogrin, M., Sinjur, I., 2007. Temperaturne razmere v slovenskih mraziščih. Proteus, 69, 5, str. 198-204.

Ogrin, D., Vysoudil, M., Ogrin, M., 2013. Splošne podnebne razmere Gorenjske in lokalne podnebne razmere Kamniške Bistrice. V: Rogelj, B., Potočnik Slavič, I., Mrak, I. (ur.). Gorenjska v obdobju glokalizacije. Ljubljana, Znanstvena založba Filozofske fakultete. Str. 9-30.

Ogrin, M., 2007. The minimum temperatures in the winter 2006/07 in Slovenian frost hollows and cold basins. Dela, 28, str. 221-237. 
Ogrin, M., Sinjur, I., Ogrin, D., 2006. Minimalne temperature v slovenskih mraziščih pozimi 2005/2006. Geografski obzornik, 53, 2, str. 4-12.

Ortar, J., 2015. Pojav znižane meje sneženja (osebni vir, 2. 4. 2015). Ljubljana.

Ortar, J., Ogrin, M., Vertačnik, G., Sinjur, I., 2010. Primerjava temperaturnih razmer v mraziščih Reovce (Orjen), Valoviti Do (Durmitor), Luknja in Mrzla Komna (obe Julijske Alpe) v meteorološki zimi 2007/2008. V: Geoekologija XXI vijeka : teorijski i aplikativni zadaci : zbornik referata $=$ Geoecology - XXI century : theoretical and applicative tasks : proceedings of the symposium. Nikšić, Filozofski fakultet, str. 553-561.

Sinjur, I., 2015. Pojav znižane meje sneženja (osebni vir, 25. 3. 2015). Ljubljana.

Steinacker, R., 1983. Diagnose und Prognose der Schneefallgrenze. Wetter und Leben, 35, str. 81-90.

Stewart., R. E., 1992. Precipitation types in the transition region of winter storms, Bulletin of the American Meteorological Society, 73, str. 48-51.

Trošt, A., 2008. Zbirka mrazišč v Sloveniji : splošni opisi mrazišč. Diplomsko delo. Ljubljana, Univerza v Ljubljani, Filozofska fakulteta, 85 str.

Unterstrasser, S., Zängl, G., 2006. Cooling by melting precipitation in Alpine valleys: An idealized numerical modelling study. Quarterly Journal of the Royal Meteorological Society, 132, str. 1489-1508. DOI: 10.1256/qj.05.158.

Velkavrh, A., 2015. Pojav znižane meje sneženja (osebni vir, 8. 4. 2015). Ljubljana.

Vremenska napoved v preteklosti. Slovreme.net. URL: http://www.slovreme.net/preteklost.asp?1=2015 (citirano 18. 5. 2015).

\section{LOWERED SNOW LINE PHENOMENON INTHE AREA OF PLANICA VALLEY AND MT. PEČ (TROMEJA)}

\section{Summary}

When snowing, level of freezing point tells us when snowflakes start to melt. Time and length of melting depends on intensity and size of snowflakes, but isolated snowflakes among raindrops can reach even 500 meters below the freezing point - also depending on temperature gradient. During precipitation, melting of snowflakes can result in drop of temperature and lowering of the snow line (Kain et al., 2000; Unterstrasser, Zängl, 2006). Usually, the diabatic and adiabatic processes, which include advection and rising of air, are stronger than processes related to melting (Kain et al., 2000). But in some cases, when the atmosphere under freezing point decouples from the air above, melting of snow can cool the layer of air where melting takes place. If precipitation is strong enough and lasts long enough, this process can cause drop of snowline to the ground and formation of isothermal layer with temperature $0{ }^{\circ} \mathrm{C}$ or very little above. In the paper, results of the research of temperature conditions during precipitation event in Planica Valley and on slopes of Peč (Tromeja)/Dreiländereck/Monte Forno (Western Karavanks) in the extreme northwestern part of Slovenia, are presented. Six temperature stations were located especially for this research and one was used from measuring network of 
Slovenian Environment Agency to form a profile line from elevation about $1400 \mathrm{~m}$ in Planica Valley to the bottom in village Rateče $(864 \mathrm{~m})$ and again up to elevation 1400 $\mathrm{m}$ on slopes of Peč (Tromeja)/Dreiländereck/Monte Forno mountain. We analyzed the precipitation event on night from March 25 2015 to March $26^{\text {th }} 2015$ when cold front passed the area. Analysis of temperature conditions in meteorological stations around the area showed that during precipitation event there was no cold advection under $2500 \mathrm{~m}$, in fact, data showed even small temperature rise. However, during the period of strongest precipitation, temperatures on our monitoring stations fell close to freezing point and for short period isotherm profile was formed in the Planica Valley so snowline reached valley bottom for a few hours. Data also show that during strongest precipitation and cooling, wind speed at the valley bottom decreased to almost calm, which indicates decoupling of air in the lower part of the valley from the air above. During the lowering of snowline, the process of cooling was stronger above the Planica Valley compared to process of cooling above slopes of Peč (Tromeja)/Dreiländereck/Monte Forno, which indicates stronger precipitation and capture of cold air in the narrow valley.

(Translated by the authors) 